\title{
Adoption of the Creative Process According to the Immersive Method
}

SONJA VUK ${ }^{\star 1}$, TONKA TACOL ${ }^{2}$, AND JANEZ VOGRINC ${ }^{3}$

$\approx$ The immersive method is a new concept of visual education that is better suited to the needs of students in contemporary post-industrial society. The features of the immersive method are: 1) it emerges from interaction with visual culture; 2) it encourages understanding of contemporary art (as an integral part of visual culture); and 3) it implements the strategies and processes of the dominant tendencies in contemporary art (new media art and relational art) with the goal of adopting the creative process, expressing one's thoughts and emotions, and communicating with the environment. The immersive method transfers the creative process from art to the process of creation by the students themselves. This occurs with the mediation of an algorithmic scheme that enables students to adopt ways to solve problems, to express thoughts and emotions, to develop ideas and to transfer these ideas to form, medium and material. The immersive method uses transfer in classes, the therapeutic aspect of art and "flow state" (the optimal experience of being immersed in an activity)/aesthetic experience (a total experience that has a beginning, a process and a conclusion)/immersive experience (comprehensive immersion in the present moment). This is a state leading to the sublimative effect of creation (identification with what has been expressed), as well as to self-actualisation. The immersive method teaches one to connect the context, social relations and the artwork as a whole in which one lives as an individual. The adopted creative process is implemented in a critical manner on one's surrounding through analysis, aesthetic interventions, and ecologically and socially aware inclusion in the life of a community. The students gain the crucial meta-competence of a creative thinking process.

Keywords: context, creative process, ideas, immersion, teaching process

$1 \quad{ }^{\star}$ Corresponding Author. Academy of Fine Arts in Zagreb, Croatia; sonja.vuk@gmail.com

Faculty of Education, University of Ljubljana, Slovenia

Faculty of Education, University of Ljubljana, Slovenia 


\section{Uvedba ustvarjalnega procesa po imerzivni metodi}

Sonja VuK ${ }^{\star}$, Tonka Tacol In JANEZ Vogrinc

$\propto$ Imerzivna metoda je obravnavana kot nov koncept v likovnem izobraževanju, ki bolj ustreza potrebam dijakov v trenutni postindustrijski družbi. Izhaja iz naslednjih postavk: 1) interakcija z likovno kulturo; 2) spodbujanje razumevanja sodobne umetnosti (kot integralni del likovne kulture); 3) implementiranje strategij in procesov prevladujočih tendenc $\mathrm{v}$ sodobni umetnosti (umetnost novih medijev in relacijska umetnost) s ciljem uvedbe ustvarjalnih procesov, ki poudarjajo izražanje posameznikovih misli in čustev ter komuniciranje z okoljem. Metoda omogoča transfer ustvarjalnih procesov s področja umetnosti na proces samostojnega ustvarjanja učencev. To se zgodi s pomočjo mediacije algoritemske sheme, ki omogoči študentom, da prevzamejo poti reševanja problemov, izražajo misli in emocije, razvijajo ideje in jih prenesejo v oblike, medije in v materiale. Metoda uporablja transfer v razredu, terapevtski vidik umetnosti in "stanje toka « ter estetsko in imerzivno izkušnjo. To je stanje, ki vodi k sublimitivnim učinkom ustvarjanja (identifikacija s tistim, kar je bilo izraženo) pa tudi k samorealizaciji. Imerzivna metoda uči posameznika, da poveže vsebino, socialne odnose in umetniško delo v celoto, v kateri živi kot posameznik. Prevzeto je implementirano na kritičen način glede na posameznikovo okolje prek analiz, estetskih posegov ter ekološke in socialno zavedne inkluzije v življenje skupnosti. Učenci pridobijo bistvene metakompetence, procese ustvarjalnega razmišljanja.

Ključne besede: kontekst, ustvarjalni proces, ideje, imerzija, proces poučevanja 


\section{Introduction}

Visual education does not typically incorporate the strategies students use in everyday life in the visual culture that has been created by new media technologies. The production and development of ideas is omitted, there is no discussion on ways of creating art (Freedman, 2003), no analysis of art's connections with social, cultural and political subjects and contexts, and no perception of society and the individual as a whole. Mere data transfer omits emotions from the learning process, it fails to develop intuitive processes, flexibility, fluency, originality or operationalisation capabilities, and it does not prepare students for active participation in society. The impression of an artwork as a communication channel with the environment is missing; there is not expression of thoughts and feelings, so there is no sublimation effect and self-actualisation. Visual education must therefore be steered towards the development of cognitive processes that include the psycho-biological and socio-cultural aspects necessary for orientation in contemporary postmodern society, so that students can become involved in their environment on multiple levels. With this in mind, visual education should take into account the powerful didactic character of visual culture and adopt creative processes and strategies from contemporary art in the development of students' creativity, enabling expression and communication with the environment and its active modification in order to establish a contemporary society with better qualities. All of this is taken into account in the immersive method.

\section{The Immersive Method}

The term "immersion" (Lat. immergere) primarily describes the effects of digital technology (new media): description of VR (virtual reality), installation art, video games, user interfaces, $3 \mathrm{D}$ computer graphics and various types of simulators (e.g., driving, flying, educational content simulators). It is a term that defines a mental condition in which consciousness of the physical "I" vanishes or is lost in thoroughly penetrating the environment. The experience of immersion includes total presence and separation from the external physical world, deep inclusion and preoccupation; it provides information or multiplesensory stimulation. Immersion is among the key strategies of contemporary new media art (Strehovec, 2003).

In educational philosophy, the "immersive" experience - comprehensive immersion in the contemporary new media environment (Strehovec, 2003) - is an aesthetic experience, a total experience that has a beginning, a process and a conclusion 
(Dewey, 1934/2005). In the case of art, this is the experience of a thorough creative process that has self-actualisation and sublimation as its ultimate effect, in the sense of identification with that which is expressed (Maslow, 1968/1999). In psychology, it is an "optimal experience based on the concept of flow - the state in which people are so involved in an activity that nothing else seems to matter" (Csikszentmihalyi, 1990, p. 4), "Concentration is so intense that there is no attention left over to think about problems. Self-consciousness disappears, and the sense of time becomes distorted. An activity that produces such experiences is so gratifying that people are willing to do it for its own sake" (Csikszentmihalyi, 1990, p. 71). Didactics achieves a similar effect in classes that include not only intellectual (cognitive), but also emotional experiences (Poljak, 1991), transfer (Tacol, 2003) and intrinsic motivation.

The starting points of the immersive method are:

1) From visual culture and contemporary new media art, the immersive method borrows the communication effects of images as an exchange of meanings and concepts. It also takes algorithmic thinking in the sense of a permanent selection of ways to handle visual, verbal and audible "units" of information (Strehovec, 2003), that is, figurative, symbolic, semantic and behavioural information (Guilford, 1968). The brain performs similar information processing in the cognitive and creative process when it selects and chooses, analyses, separates, filters, reduces, thickens, abstracts and looks for common denominators. The immersive method adopts the use of new media and communication technologies from the students' everyday lives because "schools should utilize advantages of the new media and become an active part of the postmodern culture of the young people" (Ule, 2008, p. 197). Didactically speaking, the immersive method assumes the interactive and interdisciplinary approach characteristic of visual culture and art. It includes problem solving, experience, exploration, dialogue, cooperative learning, independent learning, selection and decision, connections between different subjects and an individualised approach to the student. An algorithmic approach is used in the division of the creative process and project-based classes (clear problem idea and goal/problem learning, exploratory work/exploratory learning, an algorithmic approach, predefined methods and evaluation criteria). The advantages of such division are known: "The students who were given well-structured and precise instructions for work demonstrated significantly more creativity in realization of tasks than the students who received less structured instructions" (Niu \& Liu, 2009; according to Juriševič, 2010, p. 422). The process implements analytical thinking, which divides the given problem into more familiar smaller parts, while the development of new free associations enables the creation of a synthesising capacity to reconstruct the whole by collecting information in new ways. 
2) Contemporary art enables students to learn forms of social relations that emerge in relational art, and to manage the strategies of contemporary new media art, which is essential for orientation in new media environments. There is no difference between contemporary art and so-called popular culture (Carroll, 1998), which is today predominantly visual. Through understanding contemporary art, students adopt tools that can be used for the critical evaluation of visual culture.

3) The immersive method implements the creative process of art in the creative process of students' artwork creation. The creative processes of contemporary art are based on new solutions for societal problems, the production of ideas and the creation of new relations, while the focus is transferred from the artefact to the process, as "there can be creative thinking even when there is no tangible product" (Guilford, 1968, p. 121). Education that emerges from all of this is based on a postmodern dimension of art; namely, the interaction between individuals, groups, cultures and their contexts, as well as between various types of professional disciplines (Freedman, 2003). Given that "individuals in general possess some degree of the same creative trait or traits" (Guilford, 1968, p. 98), education that is based on the development of creativity allows all students regardless of their talent-based preconditions, average grades, motivation or problems - to achieve a basic level of creative thinking.

The immersive method concerns the adoption of a creative process aimed at the comprehensive expression of students' thoughts and feelings in artwork, their communication with the environment through an active attitude towards it, and their self-actualisation. It allows us to divide the creative process in teaching into specific stages, which are then used to guide students towards aesthetic experience/flow state/immersive experience. There are several linear forms of creativity models that, in combination with Guilford's non-linear creativity factors, can be connected with the stages of the immersive method. The linear models are Dewey's model (1910) of problem-solving, Wallas' model (1945) of creative production, and Rossman's model (1931) of invention (according to Guilford, 1968), while creativity factors are "sensitivity to problems, ideational fluency, flexibility of set, ideational novelty, synthesizing ability, analysing ability, reorganizing or redefining ability, span of ideational structure, and evaluating ability" (Guilford, 1968, p. 95). Problem solving, which forms the basis of Dewey's model, overlaps with Guilford's claim that "creative thinking and problem solving are essentially one and the same phenomenon" (Guilford, 1968, p. 122). Dewey divides the initial phase of the creative process into: the problem (difficulty) is felt, the problem is located and defined. Similarly, in Rossman's model we have: 
the problem is formulated. In the immersive method, the problem is extrapolated from 1) universal themes through “'filtering... new and more operational name for 'attention"' (Guilford, 1968, p. 41). This is the starting point and fundamental question, the basic items of a successful learning process (Gardner, 2004). The information and impressions on a given or selected universal theme are first gathered. This takes place in parallel with the preparation stage of the gathering, sorting, reduction and evaluation of the encompassed information and materials in Wallas's model, and the stage of "available information surveyed" in Rossman's model. The problem that functions as the initial subject of the student's artwork is then extrapolated. This learning process is based on shifting from the universal to the particular, from the whole to the detail. Universal themes have nurture value and pose ethical and moral questions (Gardner, 2004). This corresponds to the concept of Guattari's "three ecologies": the environmental, the social and the mental (Baudrillard, 1972/2013). These are the so-called universal themes of truth, goodness and beauty (Gardner, 2004), e.g., environmental pollution, interpersonal relations, tolerance towards difference, etc. Thinking about the creation of new forms of social relations aimed at inspiring understanding and responsibility among students is encouraged through the detection of problems in the universal themes (Gardner, 2004). A problem extrapolated from a universal theme is connected with the personal experience of the students, thus giving us 2) a generative theme (Freire, 1970/2010), which connects the universal questions with the students' practical, emotional and intellectual experience. At this stage, a framework goal is defined within the immersive method: that which one aims to communicate, the message that one wishes to send to the surroundings. Through free associations, metaphors, symbols and codes, the generative theme is extrapolated into 3 ) an idea, which must be both new and useful in a certain social environment (Flaherty, 2005). This process of the development and production of ideas most resembles Wallas's incubation stage, which is unconscious work. At this stage of the immersive method, the students learn and implement techniques for idea production, such as brainstorming and techniques for stimulating lateral thinking (De Bono, 2007), so that work on the development and production of ideas is not limited to the unconscious level. This enables the development of divergent production, the "generation of ideas, as in solving a problem, where variety is important" (Guilford, 1968, p. 142). In divergent production, "the goal is to produce a variety of ideas, all of which are logically possible in view of the given information" (Guilford, 1968, p. 156). In order to define the best possible solution - that is, to select the most original idea - convergent thinking, in sense of the recognition of the best solution, is implemented (Guilford, 1968). This is defined as suggesting the possible solutions 
in Dewey, as illumination (solutions emerge) in Wallas, and as formulation of solutions in Rossman. The immersive method adds two segments to this linear stage; namely, the transposition of the idea into 4) form, for which appropriate 5) media and material have been found. Here, too, the establishment of an appropriate form for the given content, along with the divergent thinking, develops complementary cognitive thinking aimed at finding the best possible solution. During the entire process, the student is encouraged to engage in 6) reflection, which constantly diverts his/her attention towards the connection between what has been done and what has been experienced, towards a subjective feeling of satisfaction with work and the association of this feeling with the result. In linear models, this can be seen as realising the consequences in Dewey, as verification (solutions tested and elaborated) in Wallas, and as solutions critically examined in Rossman, while Guilford sees it as evaluation. Discovering a conclusion in this process creates a sense of surprise, which is a source of satisfaction and selfactualisation. Identification with what has been expressed, 7) sublimation, occurs, and this is the therapeutic effect of art. 8) Analysis of results and remediation (Bolter \& Grusin, 2000) in the immersive method correspond with acceptance of the solution in Dewey, and with formulating new ideas and their testing and acceptance in Rossman. In the immersive method, this is the stage in which the entire process is reconstructed, in which the ideas and the message of the work are recognised, while the relation between the form, the content and the media is analysed. A division into visual language, symbolic language and semantic language - in the sense of decoding the meaning - takes place. One discovers the causalities in one's own work, the sequence of work, and the motivation; various ways of presentation are realised, along with the relationship between character and style, material and media, as well as the interpretation of the initial theme; the handwriting, emotional impression, etc. are analysed, all of which are connected with the given teaching content (remediation), comprising formal analysis (division into visual language), analysis of the media and material (technical aspects), and analysis of the aesthetic component (composition elements in relation to the intuitive processes). This is a comprehensive process that encourages and develops creativity (the process of connecting previous experience with responses to stimuli, and the creation of at least one unique combination), originality (the production of unusual, hard to achieve, farfetched and ingenious solutions), fluency factors (idea, association, expression), flexibility factors (spontaneous, adaptive), redefinition, sensibility towards problems, perceptive capabilities, elaboration and critical position (Guilford, 1968).

In formal implementation, the immersive method is supported by the everyday language of the students' visual environment, which is created though 
new media and communication technologies, and is close to the strategies of contemporary new media art: immersion, acts of dispersion, recycling, mixing and sampling, tactility, simulation, suspense, interactivity, action, ludic, performative, fluid and processual character (Strehovec, 2007), as well as to strategies of relational art, in the sense of transferring the relations to a material framework (aesthetics), their incorporation into artistic references (historical), and finding a consistent position in relation to current social relations (social). In the immersive method, the strategies of contemporary art serve as mediators in the transfer of teaching content, ideas and messages (cognitive and emotional content) to the result of the creative process (form). These strategies represent a way of dealing with forms, materials and media.

\section{Empirical Research}

The number of subjects: The immersive method was implemented in regular art classes in the 2012/2013 school year. The part of the research presented here (action research) encompasses three fifth-grade classes (students aged 11 years) of compulsory eight-year primary schools located in Zagreb, Croatia, as well as three specialised art teachers.

Problem and research questions: In relation to the basic problem of the research - how to improve implementation of art classes in practice - the goals of the research provide answers to the following questions: 1) How can the immersive method be implemented within the framework of the existing teaching programme? 2) How can the focus of the classes be shifted towards the stimulation of creativity (the adoption of the principle of creative/lateral thinking, i.e., the scheme of the creative process)? 3) How can the affective aspect of classes be encouraged (encouraging interest in moral and ethical issues, forming positive attitudes, establishing a critical attitude towards one's environment, developing an ability to connect art-related activities with life in order to achieve transfer and sublimation of the influence of creativity in the students' inner development, and establishing visual communication with the environment)? 4) How can teachers utilise the new media and the new media strategies found in the students' surroundings in their artistic expression? 5) Does implementation of the immersive method in art classes influence the students' interest in artistic expression, the independence in their work, the application of what has already been acquired in previous classes to tasks in new classes and creativity (the process of connecting one's previous experience with responses to stimuli and forming at least one unique combination), originality (production of the unusual, farfetched, remote or clever responses), factors of fluency (ideational, associational, 
expressional), flexibility factors (spontaneous, adaptive), redefinition, sensitivity to problems, perceptual capabilities, elaboration and critical attitude?

Research Methods: action research, four-step developmental approach (Vogrinc, 2008); so-called performative research (Vogt, Pfeil, \& Seitz, 2009, p. 26);

Research techniques: questionnaire polling, grading, knowledge verification, interviewing, observation, content analysis;

Research instruments were developed in order to implement the research: questionnaire, grading scales (for artwork), Likert-type scales, tasks for students, interviews (non-structured and semi-structured), observation (written and photo documentation), written notes, written and oral observations of the teachers; instruments specific to performative research.

Common instruments in all action steps: written observations from attending all classes during the entire school year. Following Kirkpatrick (1954/2014), four levels of evaluation of studying were monitored: reaction of the students (subjective feeling of success and satisfaction with the process and work, strong and weak points of the tasks, adjustment to personal styles of learning, non-verbal communication, relationship towards teaching and creative process), behaviour (method and scope of using the adopted content in furthering the teaching process, implementation of positions and behaviour, awareness of one's own changes), results (presentation and analysis of one's own work); notes on the reactions of the teachers; results of tasks (written, audio and photo documentation); non-structured interviews with the teachers; semistructured and non-structured interviews with the students; written follow-up analysis of the works (level of adoption and implementation of the teaching process, understanding of the idea and message of each work; interpretation of universal themes; the relationship between content and form, media and material); students' artwork (analysis of transfer of symbolic form to the material forms of mobile and static pictures, sounds, live action and digital code); grading scale for artwork; written tasks for the students (practices for the development of creative/lateral thinking).

The questionnaire at the end of each project consisted of the following groups of questions, tasks and Likert-type scales: 1) understanding of the universal theme; 2) understanding of how the universal themes (motives) are associated with generative topics from the student's personal experience; 3 ) verification of the teaching content (test of knowledge); 4) connecting the teaching content with the visual culture in one's own surroundings; 5) subjective experience of the teaching process (motivation, level of attractiveness of the teaching content and new type of classes, applicability of the teaching content in further life, experience of learning). 
Specific instruments for action steps: $1^{\text {st }}$ action step - written and oral tasks for the students; $2^{\text {nd }}$ action step - ludic and exploratory performative tasks; $3^{\text {rd }}$ action step - taking notes on reactions and results achieved by the students after receiving written and verbal instructions for group work (written solutions by the students, drafts, idea-development); written and audio notes of the creative process and analysis of work (self-evaluation and independent insight during the creative process; notes on self-motivated student initiatives regarding insight during the creative process and collection of additional material for classes; independence within the groups; cooperation with other group members); $4^{\text {th }}$ action step - written tasks for the students (production of a certain number of different ideas aimed at the adoption of patterns regarding the need to create multiple ideas and select an idea that is appropriate to the work's message; classification of the applicability of the ideas, the literal aspect and the farfetchedness of the associations); notes on self-motivated students' initiatives regarding insight during the creative process and collection of additional material for classes; independence during implementation of the algorithmic scheme of the creative process; sensitivity towards the universal theme.

Procedure: During classes, the students used their mobile telephones for specific visual tasks, documenting the creative process and the artwork, and executing Internet searches in order to collect the information and visual materials necessary for the teaching process. Each action step corresponded with a project within the teaching subjects that had been organised and presented.

The following changes were introduced according to the action steps:

$1^{\text {st }}$ action step: introduction of teaching methods (Mattes, 2007) and strategies (Marzano, Pickering, \& Pollock, 2006) corresponding to the subject, and introduction of strategies of contemporary new media art corresponding to the formal aspect of the tasks and exercises for encouraging lateral thinking (De Bono, 2007). This was introduced in the classes with the use of oral, written and performative tasks, as well as communication technologies (mobile telephones).

The first action step/project included teaching the subject point and line, as well as units from the teaching plan and programme: Shape Lines, Flow and Character of Lines; Structural Points and Lines; Structural Lines. Duration of the project: six teaching hours.

Universal theme: Introduction to the subject of affirmative communication (the communication chain begins when the teacher gives an example, after which the students devise complex affirmative questions focused on the positive characteristics of the person they address); ways of communicating as 
a means of expressing thoughts and feelings (encouraging the students to performative expression of their feelings and behaviour in communication with the others, recognition and analysis of relationships, connection with visual metaphors in everyday speech); visual communication (verbal and non-verbal types of communication, inclusion of all of the senses in communication and connection with visual expression).

Generative theme - connecting with the students' personal experience: connection with examples from the students' everyday life (class, school, friends, etc.); written notes on the events, whether real or imaginary (technique for stimulating lateral thinking: random word technique in which each student draws a piece of paper containing five random words and chooses two of them, of which they must put one at the beginning of the story and the other at the end);

Setting the goal and idea extraction: extracting the basic feeling from a story aimed at its non-verbal presentation (stimulating lateral thinking: string technique in which five associations on feelings are defined); extraction of the main feeling, discussion on the message, on how to visually present a feeling that it could be recognised by others;

Searching for the appropriate form for given content; Media and materials: art task 1) visual message through a point and line - mobile phone text message (example: sorrow \%[ [ I*].!*_* ?? \}!!!!-----\} $0 . .) ;$.2 ) visualisation of abstract notions (feelings) through traditional media, drawing and collage (within a drawn silhouette of their own bodies, the students positioned extrapolated emotions and visualised them through the technique of collage of the photocopied examples of visual communication reduced to point and line, pictures of nature, artwork and their text messages); two examples are given in Figure 1 and Figure 2;

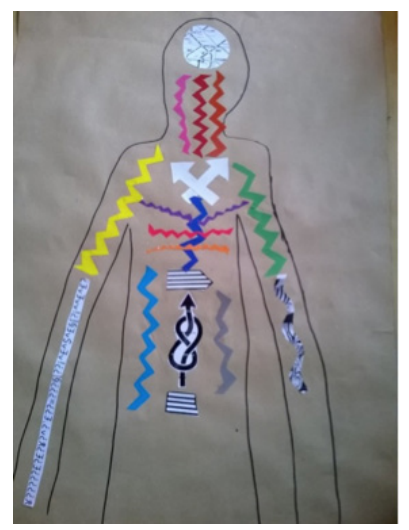

Figure 1



Figure 2 
Reflection and analysis; remediation: During practical work, the students were encouraged to proceed with the deliberation and analysis of their works, and to consider which of the materials offered they would use for expressing the foreseen content. Analysis of the students' artwork through pre-prepared tasks, and recording their answers to given tasks; reconstruction of the results, i.e., processing of the teaching content, the strategy of contemporary new media art and implementation in visual culture: dispersion (composition), recycling, mixing and sampling (collages). Verification of what has been adopted.

$2^{\text {nd }}$ action step: encouraging of intrinsic motivation among the students (generative themes); introduction of clear rules on steering the students' emotional and cognitive content towards appropriate forms and media; contemporary new media art strategies implemented in processing the teaching content (performativity, interactivity).

The second action step/project included teaching the subject colour, as well as units from the teaching programme: Light Values of Clear Colours; Clear Colours, Warm-Cold Contrast; Complementary Contrast. Duration of the project: six teaching hours.

Universal theme: Continuation from the universal theme in the $1^{\text {st }}$ project on communication

(discussion on colours people like to wear and the reasons for this, as well as what our choices

communicate to the surroundings; discussion on colours found in the environment);

Generative theme - connecting with the students' personal experience: Performative tasks related to the implementation of colour in the students' lives and association plays that connect colours with emotions; written tasks that require presenting one's favourite colour (students write a short story on their favourite colour, explaining why and when it became their favourite colour and describing an event in their lives from the time this colour became their favourite);

Setting the goal and idea extraction: extracting the basic idea and message from each story; discussion on visualisation of ideas through colours;

Searching for the appropriate form for given content; media and materials: visual task - visualisation of one's personal story through colour, expression of the dominant emotions in a story, tempera technique (basic parameters for using the technique are given; directions for at least three clear colours and three mixed colours). Examples in Figure 3 and Figure 4. 




Figure 3

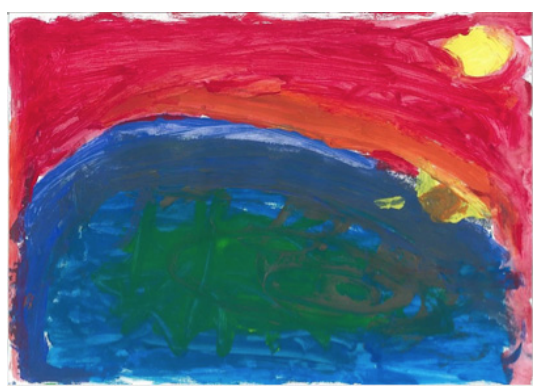

Figure 4

Reflection and analysis; remediation: During the practical work, the students were encouraged to proceed with the deliberation and analysis of their own works, as well as to think about their next steps. Analysis of the students' artwork through pre-prepared tasks and recording their answers to given tasks (recognition of emotion in the painting emerging from the combination of colours, idea recognition; discussion on expressing feelings in an acceptable way); reconstruction of the results - processing of the teaching content. Verification of what has been adopted.

$3^{\text {rd }}$ action step: introduction of self-evaluation and independent deliberation during the creative process. The third action step/project included the teaching subject surface and flat space, as well as units from the teaching plan and programme: Static and Dynamic Plane; Figures on a Plane; Redefinition of a Plane; Graphic Modelling; The Rhythm of Shapes and Textures; Painting Textures. Duration of the project: 12 teaching hours.

Universal theme: Continuation from the universal theme in the $1^{\text {st }}$ project on visual communication (posters and messages, impact on the environment); connection with a subject related to ecology and health (the groups received three themes and appropriate materials, written tasks and lists of roles within each group, which the students divided among themselves); conversation on the connection between the individual and society, as well as on how much each individual can contribute to general progress in the preservation of the immediate environment; how to influence others in order to increase awareness on the importance of environmental protection; each group presents their theme from the materials they have received or collected independently (the Internet).

Generative theme - connecting with the students' personal experience: written tasks related to one's own experience about the given subject (students write short stories on their own experiences connected with the data included in the informative materials); 
Setting the goal and idea extraction: extracting the basic idea and message from each story; discussion on visualisation, as well as ideas and messages in the form of a poster aimed at warning other students in the school;

Searching for the appropriate form for given content; media and materials: tasks preceding the main task and aiming at physical (unconscious) perception of the teaching content: 1) conceiving and developing a board game (strategies of new media art - action and ludic character); 2) finalising the given detail; 3) main artwork task: each group is given a particular task (in terms of both form and theme) according to which it visualises the extracted idea into a poster with a clear message (strategies - tactility, simulation). Examples of posters are presented in Figures 5 and 6;

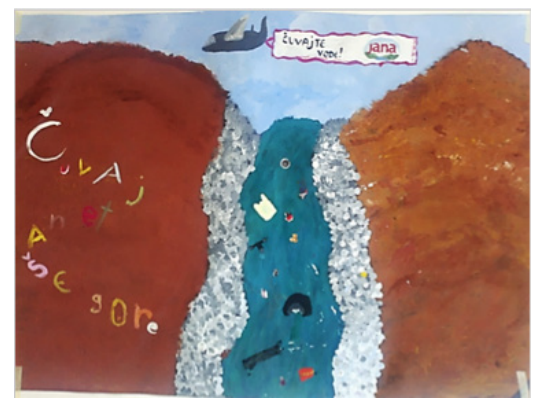

Figure 5

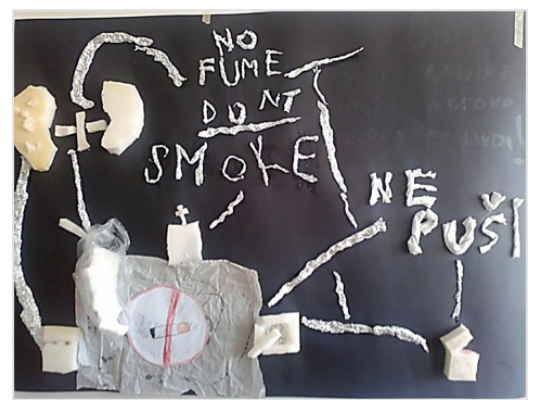

Figure 6

Reflection and analysis; remediation: During the practical work, the students were encouraged to proceed with the deliberation and analysis of their own works, as well as to think about their next steps. Analysis of the students' artwork through pre-prepared tasks and recording their answers to given tasks; reconstruction of the results - processing of the teaching content. Feedback from the surroundings. Verification of what has been adopted.

$4^{\text {th }}$ action step: introduction of partial independence of the students in creating and managing their own projects: teacher becomes a mediator, while the students adopt and independently implement an algorithmic scheme of the creative process; sensibility to universal themes (independence in selection, sensibility towards the context, empathic insight, flexibility, critical attitude towards the surroundings).

The fourth action step/project included teaching the subject mass/volume and space, as well as the teaching units: Basic Three-Dimensional Forms; Proportions of Three-Dimensional Forms (Bodies) in Space; Complex Space 
Structures and Constructions. Duration: six teaching hours.

Universal theme: Discussion on the situation of students and children in other parts of the world, as well as on the right to and availability of schooling (analysis of examples of stories of children working in toy factories and cocoa plantations);

Generative theme - connecting with the students' personal experience: the students' attitude towards school (comparison of one's own living conditions with those of the children in the stories, discussion on one's own capabilities and encouraging empathy for others); written tasks (production of a given number of ideas focused on helping the children from the stories; divergent thinking); performative tasks (body perception of the teaching content: development of layout and establishment of a relationship between the figures and the space based on data from the given story);

Setting the goal and idea extraction: students choose the most interesting ideas in the group, extracting the basic idea and message from each group work session; discussion on visualisation of ideas and messages in the form of an animated video; development of a storyboard;

Searching for the appropriate form for given content; media and materials: artwork task - making individual shots for an animated video and editing them into an animated video (strategies of new media art - suspense, process), stills from animated videos are presented in Figures 7 and 8;

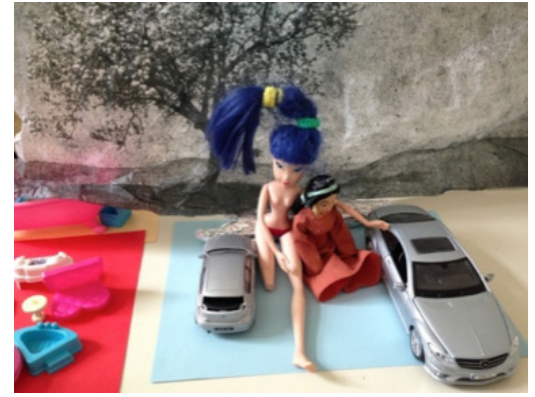

Figure 7

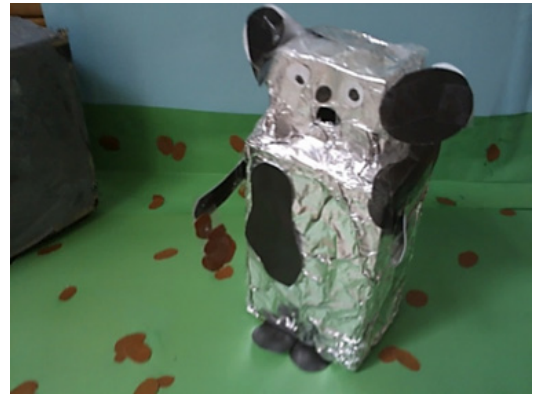

Figure 8

Deliberation and analysis; remediation: the students were expected to proceed with independent deliberation and analysis of their own works, and to implement the stages of the creative process. Analysis of the students' artwork and reconstruction of the results - processing of the teaching content. Verification of what has been adopted. 


\section{Results and interpretation}

The results based on all of the instruments used show that the students adopted the immersive method as a way of creative thinking. Positive reactions and high intrinsic motivation were recorded for all four action steps, particularly during the visualisation of the students' own cognitive and emotional content. The results obtained from the instruments of written tasks (practice for encouraging lateral thinking and idea development, brainstorming), performative tasks and ludic tasks show that all of the students accepted these tasks as an integral part of the classes, and that they accepted guidance in defining clear visual messages.

The results confirming the successful implementation of the visual tasks with the majority of the students were obtained through instruments such as the students' artwork, the evaluation scale for the artwork, and the written and verbal insight of the teachers. It was not difficult to understand the ideas and messages contained in the artwork, while the solutions - according to the goals - were pronouncedly individual and original. For the purposes of the research, an evaluation scale for artwork was devised that comprised the following categories: understanding and implementing key terms and other teaching content; conceptual thinking (transfer of ideas into form); variation in the process of transfer of ideas into form; originality (production of unusual, farfetched, remote and ingenious solutions); perception of the whole (details subordinated to the whole); deliberation on one's own creative process; sensitivity towards guiding through the process (from being dependent to being independent); reaction to criticism during the creative process (from the teachers and the students); handling the techniques and materials (selection and implementation); variations in implementation; technical skills (orientation in already known and unknown media); completeness of the artwork (realisation of the idea in form, media and material). The majority of the criteria showed a visible increase in the grades $(1<5)$ over the process from the $1^{\text {st }}$ project to the $1^{\text {st }}$ task in the $3^{\text {rd }}$ project, after which the grades for all of the criteria were mainly 5 . The exceptions were the criteria of originality and variations in the process of transfer of ideas into form, in which the maximum average grade (5) was only achieved in the $3^{\text {rd }}$ task of the $3^{\text {rd }}$ project. With regard to criteria related to the completeness of the works, conceptual thinking and the perception of the whole, all of the students received a grade of 5 in the $1^{\text {st }}$ task of the $3^{\text {rd }}$ project; the grades decreased slightly in the $2^{\text {nd }}$ task, only to grow again to the maximum in the $3^{\text {rd }}$ task. Comparison of the $2^{\text {nd }}$ project and the $1^{\text {st }}$ task in the $3^{\text {rd }}$ project: the grades differ significantly only in the criteria of handling the techniques and materials, acceptance of guidance during the process, variations in implementation and 
technical skills $(\mathrm{p}<0.05)$, in which significantly higher grades were recorded for the $1^{\text {st }}$ task of the $3^{\text {rd }}$ project. No significant difference was recorded between the grades in the $1^{\text {st }}$ project and grades in the $1^{\text {st }}$ task of the $3^{\text {rd }}$ project for the criterion of originality $(\mathrm{U}=252.000, \mathrm{p}=0.447)$. Comparison of the $2^{\text {nd }}$ task in the $3^{\text {rd }}$ project and the $3^{\text {rd }}$ task in the $3^{\text {rd }}$ project: the grades do not differ significantly, except for the criteria of conceptual thinking, originality and completion of the works $(\mathrm{p}<0.05)$, in which the grades are significantly higher in the $3^{\text {rd }}$ task of the $3^{\text {rd }}$ project. Comparison of the $3^{\text {rd }}$ task in the $3^{\text {rd }}$ project and the $4^{\text {th }}$ project: the grades do not differ significantly (almost all of the grades are 5). The percentage of completed and defined works grows during the action steps from a larger number of unfinished works in the first action step to all of the works being finished in the third and fourth steps. Analysis of the transfer of symbolic and semantic forms to material forms shows a level of adoption of the algorithmic scheme of the creative process.

During the third action step, the students used the Internet on their mobile telephones independently in order to expand the textual and visual information on the given subject, while, in the fourth step, they independently used their mobile telephones in order to find options for better implementation of the task. During the implementation of the task, all of the groups showed independence in decision making regarding content and form, as well as selforganisation in terms of work discipline and insight, discussion on the clarity of the message and formal quality of the works. An increase in empathy between the students, cooperation and mutual respect was noticed. Based on the instruments of written tasks for the students (production of a certain number of different ideas based on the same subject), it was determined during the fourth action step that the students adopted patterns of creating multiple ideas and selecting the best ideas for the message of the work. The students were also independent in their decisions when it came to the formal aspects of the works and determining the stages in the working process, connecting and including content of other classes and teaching subjects, and self-organization in the division of tasks and their implementation (either through voting or agreement). The recording of analyses throughout all four action steps shows an increased desire for equal participation in the analysis of other students' works and detailed analysis of one's own work. During the analysis at the end of the fourth action step, the students independently use teaching content and key terms. Some students work independently at home, while explanations of such work showed a need for the use of the therapeutic effect of art in classes (Bilić, 2012).

According to the questionnaire results, a high level of adoption and implementation of teaching content was determined (some $70 \%$ for all action 
steps, while invalid or incorrect answers were mostly connected to a lack of understanding of the questions in the questionnaire), as well as a high level of understanding of the universal theme.

An analysis of several layers of the works (various levels of meaning and perception) was established. During the analysis, the students first read the subject of the work on an intuitive level, and then implemented the adopted information and knowledge in formal analysis and remediation. The analysis included deliberation of the entire working process, analysis of the ideas in each work and their context in real life, the method of transferring idea to form, as well as connections with the teaching content. Based on the Likert scales in the questionnaire, the following answers prevailed in all of the grades for all four projects: I had good time in the classes; I learned something and it is fun for me; I learned a lot, it is interesting and fun for me; it is sometimes fun for me; this will be useful in everyday life. The following answer was recorded in several cases: it is sometimes interesting and fun for me, I am not sure what I have learned. The results indicated the following changes: adoption and implementation of the creative process according to the immersive method (encouraging creative/lateral thinking); adoption of the techniques for idea development and production; sensitivity towards ethical and moral questions (critical thinking about one's environment and consideration of whether it is possible to intervene in it within one's own capabilities); formulation of clear visual messages; identification with one's own artwork; acceptance and adoption of the rules of project-based classes. All of the foreseen changes were achieved. In the final deliberation and analysis, the students agreed that the new type of class was interesting and fun, but that they had to think and be active constantly, which is something they were not used to doing.

\section{Conclusion}

The results of the research on the target sample and the case studies enable the introduction of an alternative method that could allow students to adopt and implement the structure of a creative process aimed at creative problem solving, creating original ideas, expressing thoughts and feelings, communicating with the environment, being sensitive to moral and social issues, forming a critical attitude and achieving self-actualisation. This type of class increases student participation in planning and implementing classes based on a social subject. Student motivation is encouraged, along with identification with one's own work (the sublimative effect of finding an appropriate form for the given content), questioning of one's own environment, assuming positions and acting 
accordingly. The classes were connected with the visual culture of the students' everyday environment through the use of the strategies of contemporary new media art as mediators in idea transfer to the result of process (handling the forms, materials and media), as well as relational art (establishing social relations). The new approach offers an answer to the question of how to advance students' insight into their own thoughts, feelings and experiences, encouraging their communication with the environment and developing their critical position towards it. In the process of adopting a creative way of thinking, the students gained a crucial meta-competence that they can critically implement in their own environment though analysis, social, ecological and aesthetic awareness, problem solving, and independently changing one's own environment. The analysis of all of the results determined the successful implementation of the immersive method in the regular teaching process according to the teaching programme, while the description of the procedures and the analyses of the results provides answers to all of the research questions. To date, art didactics has not included a universal method that would be applicable to all educational levels and all educational systems, and that would take into account the creative processes, visual culture, the nurture aspect and the therapeutic effect of art.

\section{Literature}

Baudrillard, J. (1972/2013). Simulacija i zbilja. Zagreb: Naklada Jesenski i Turk, Hrvatsko sociološko društvo.

Bolter, D., \& Grusin, R. (200o). Remediation:Understanding New Media. Cambridge Massachusetts: The MIT Press.

Bilić, V. (2012). Croatian Journal of Education, 13(4), 87-121

Carroll, N. (1998). A Philosophy of Mass Art. Oxford: Clarendon Press.

Csikszentmihalyi, M. (1990). Flow: The Psychology of Optimal Experience. NY: Harper Collins. De Bono, E. (1970). Lateral thinking: creativity step by step. NY, Grand Rapids, Philadelphia, St. Louis, San Francisco, London, Singapore, Sydney, Tokyo, Toronto: Harper\&Row.

Dewey, J. (1934/2005). Art as Experience. NY: A Perigee Book.

Freedman, K. (2003). Teaching Visual Culture: curriculum, aesthetics, and the social life of Art.

Columbia University: Teachers College.

Flaherty, A. (2005). Frontotemporal and dopaminergic control of idea generation and creative drive. Journal of Comparative Neurology, 493(1), 147-153

Freire, P. (1970/2010). Pedagogy of the opressed, New York: Continuum International Publishing Group.

Gardner, H. (2004). Disciplinarni um. Zagreb: EDUCA, d. o. o.

Guilford, J. P. (1968). Intelligence, Creativity and their Educational Implications. San Diego: Robert R. 
Knapp.

Juriševič, M. (2010). Creativity in the Zone of Proximal Motivational Development. In M. Valenčič

Zuljan \& J. Vogrinc (Ed.), Facilitating Effective Student Learning through Teacher Research and

Innovation. Ljubljana: Faculty of Education.

Kirkpatrick, D. (1954/2014). The Kirkpatrick Model. Retrieved 28.05.2014 from http://www.

kirkpatrickpartners.com/OurPhilosophy/TheKirkpatrickModel/tabid/302/Default.aspx

Marzano, R. J., Pickering, D. J., \& Pollock, J. E. (2006). Nastavne strategije. Zagreb: Educa.

Maslow, A. H. (1968/1999). Toward a Psychology of Being. Canada, Danvers MA, New York NY: John Wiley\&Sons.

Mattes, W. (2007). Nastavne metode. Zagreb: Naklada Ljevak d.o.o..

Strehovec, J. (2003). Umetnost Interneta. Ljubljana: Študentska založba.

Strehovec, J. (2007). Umetniško delo in besedilo v času medmrežja. Ljubljana: Študentska založba.

Poljak, V. (1991). Didaktika. Zagreb: Školska knjiga.

Tacol, T. (1999). Didaktični pristop k načrtovanju likovnih nalog, Izbrana poglavja iz likovne didaktike. Ljubljana: Debora.

Ule, M. (2008). Za vedno mladi? Socialna psihologija odraščanja. Ljubljana: Fakulteta za družbene vede.

Vogt, C., Pfeil, M., \& Seitz, H. (2009). Be Unique Be Open Be Art, Urban Culture and Youth in Berlin and Beyond or How To Do Things With Art. Potsdam/Berlin: University of Applied Sciences Potsdam. Vogrinc, J. (2008). Kvalitativno raziskovanje na pedagoškem področju. Ljubljana: Univerza v Ljubljani, Pedagoška fakulteta.

\section{Biographical note}

SonjA VuK is artist and art educator. Graduated from the Academy of Fine Arts, Zagreb, Croatia, and the Academy of Fine Arts and Art Education in Tilburg, The Netherlands, where she also finished the post-graduate studies in $3 \mathrm{D}$ art. Received post-graduate MA degree in video at the Academy of Fine Arts, Ljubljana, Slovenia, and is curently attending PhD studies in art education at the Faculty of Education, Ljubljana, Slovenia. She participated in numerous exhibitions and symposia at home and abroad with interdisciplinary art and art education projects. She is an docent at Academy of Fine Arts in Zagreb, Croatia.

JANez Vogrinc is an Associate Professor for Statistics and Methodology (2008) and Vice-dean (2010) for Doctoral Studies, Quality Assurance and Research at the Faculty of Education, University of Ljubljana, Slovenia. His main field of profession is statistics, methodology, SPSS and his current 
research interests are criteria for evaluating the quality of the scientific findings, educational concepts, the professional development of education practitioners and teaching/learning practices, action research, quality assurance. He is involved in international (e.g. Modernizing Teacher Education at University of Prishtina - MEd@UP, Evidence Based Education European Strategic Model for School Inclusion (EU ESMOSI)) and national projects (e.g. Explaining Effective and Efficient Problem Solving of the Triplet Relationship in Science Concepts Representations, Research on learning and teaching in contemporary society). 